\title{
Wprowadzenie: ontologie poznawcze i jednorodność nauk poznawczych
}

\author{
Przemysław Nowakowski \\ Ośrodek Badań Filozoficznych, Warszawa \\ pnowakowski@avant.edu.pl
}

Słowa kluczowe: ontologia poznawcza; nauki poznawcze; zadania umysłowe; konstrukty psychologiczne; dane

\section{Problemy z jednorodnością}

Nauki poznawcze są zalewane publikacjami. Baza PubMed podaje, że w samym 2016 roku opublikowano 1976 artykułów powiązanych z terminem „pamięć krótkotrwała”, 16245 powiązanych z terminem „poznanie” czy 806 powiązanych z hasłem „uwaga selektywna”. To powoduje, że problemem staje się nie tylko zapoznanie się $\mathrm{z}$ tymi wynikami czy uwzględnienia wyników $\mathrm{z}$ większości $\mathrm{z}$ tych prac - to przedsięwzięcie już od dawna skazane jest na niepowodzenie. Poważnym wyzwaniem staje się także integrowanie, a nawet produktywne zestawianie wyników badań. Bo czy na pewno w każdym ze wskazanych powyżej 806 tekstów z bazy PubMed użyto terminu „pamięć selektywna” w tym samym znaczeniu? Bardzo wątpliwe. Taka sytuacja jest spowodowana tym, że badania kognitywistyczne często są przeprowadzane $\mathrm{w}$ ramach różnych dziedzin (na przykład neuronauk, antropologii, informatyki), subdziedzin (na przykład neuronauk poznawczych, psychologii rozwojowej, filozofii umysłu), odmiennych tradycji (na przykład konstruktywizmu w psychologii, redukcjonizmu $\mathrm{w}$ filozofii, podejścia obliczeniowego w neuroanukach) i w różnych laboratoriach. Badania te wykonywane są przy pomocy rozmaitego sprzętu, dotyczą różnych obiektów (w tym różnych gatunków zwierząt), a także opierają się na wielorakich teoriach.

Efektywny rozwój nauk poznawczych wymaga maksymalnego ujednolicenia danych i metod. Umożliwi to łatwą komunikację i pozwoli na udostępnianie danych, które będą zrozumiałe dla badaczy z różnych laboratoriów i grup badawczych. Wydaje się, że nawet jeżeli zajmiemy pozycje 
pluralistyczne (akcentujące wewnętrzną niejednorodność nauk poznawczych), to aby prowadzić rzetelne badania, powinniśmy mieć możliwość zestawić ze sobą i porównać dane, metody czy rozwiązania. Jednak zadanie to nie jest proste ani latwe, także dla pluralistów. Potrzebne są skoordynowane prace metateoretyczne i metodologiczne.

W artykułach, które chcemy Państwu przedstawić (Hastings i in., ten numer; Poldrack i in., ten numer) problem braku jednorodności dotyczy pojęć konstruktów poznawczych używanych w (neuro)naukach poznawczych, a także związków tych konstruktów z zadaniami używanymi do ich badania. Oczywiście problem ten nie ogranicza się do pojęć i zadań, dotyczy także ich gromadzenia, przechowywania i udostępniania przez badaczy i wykracza poza nauki poznawcze (O’Malley i Soyer, 2012; Leonelli, 2012). Dane powinny być odpowiednio pooznaczane, uporządkowane $\mathrm{w}$ taki sposób, aby możliwe było ich (poprawne) użycie przez badaczy. Problem ten dotyczy zarówno wykorzystania pierwotnie zgromadzonych danych, jak i - a może przede wszystkim - wykorzystywania tych danych do poprawnych metaanaliz. Dobrze opracowane dane umożliwiają nie tylko powszechne użycie, ale i automatyzacje analiz (Yarkoni, 2012), a przez to uwzględnianie większej ilości wyników czy też dokonywanie potężniejszych i rzetelniejszych metaanaliz.

\section{Artykuły_2}

Tak jak wspominaliśmy, potrzebne jest rozwiązanie. Autorzy prezentowanych poniżej prac uważają, że takim rozwiązaniem są ontologie poznawcze i ich integracja. Przedstawiamy Państwu dwa tłumaczenia artykułów: pierwszy to prezentacja Atlasu poznawczego, jednej $\mathrm{z}$ pierwszych ontologii poznawczych, drugi to Interdyscyplinarne perspektywy rozwoju, integracji i zastosowań ontologii poznawczych, który zawiera syntezę bieżących prac nad rozwojem ontologii poznawczych i ich integracją (Atlas poznawczy jest tu jednym z przykładów). Prace te prezentują wstępne etapy rozwoju wspomnianych ontologii, więc trudno tu oczekiwać zadowalających rozwiązań i wyczerpujących odpowiedzi. Jesteśmy jednak przekonani, że niezwykle interesujące jest przyjrzenie się, jakimi sposobami kognitywiści zamierzają poradzić sobie - lub nawet już sobie radzą z coraz większą różnorodnością dziedziny i jak możemy doprowadzić do poznawczo zadowalającego ujednolicenia nauk poznawczych.

Czy prezentowane tu podejścia są satysfakcjonujące? Przekonamy się w przyszłości. Z pewnością mamy tu do czynienia z jednymi z najciekawszych podejść integrujących badania metodologiczne i metateoretyczne w naukach poznawczych. 
Last but not least, pragnę podziękować Marcinowi Miłkowskiemu za pomoc przy tłumaczeniu terminów informatycznych, a także dwójce wspaniałych redaktorów: Marcinowi Łysiakowi i Agacie Koprowicz, których praca umożliwiła mi uniknąć wielu pomyłek translatorskich.

\section{Literatura}

Leonelli, S. (2013). Integrating data to acquire new knowledge: Three modes of integration in plant science. Studies in History and Philosophy of Science Part C: Studies in History and Philosophy of Biological and Biomedical Sciences, 44(4), 503-514.

Leonelli, S. (2012). Introduction: Making sense of data-driven research in the biological and biomedical sciences. Studies in History and Philosophy of Science Part C: Studies in History and Philosophy of Biological and Biomedical Sciences 43(1), 1-3.

Leonelli, S. (2009). On the locality of data and claims about phenomena. Philosophy of Science, 76(5), 737-749.

O'Malley, M. A., \& Soyer, O. S. (2012). The roles of integration in molecular systems biology. Studies in History and Philosophy of Science Part C: Studies in History and Philosophy of Biological and Biomedical Sciences, 43(1), 58-68.

Poldrack, R. A.\& Yarkoni, T. (2016). From brain maps to cognitive ontologies: informatics and the search for mental structure. Annual Review of Psychology, 67, 587612.

Yarkoni, T. (2012). Psychoinformatics: New horizons at the interface of the psychological and computing sciences. Current Directions in Psychological Science, 21(6), 391-397. 